06

\title{
Получение композиционных материалов на основе карбида кремния силицированием углеродных матриц
}

\author{
(C) С.Л. Шикунов, В.Н. Курлов \\ Институт физики твердого тела РАН, \\ 142432 Черноголовка, Московская обл., Россия \\ e-mail: kurlov@issp.ac.ru
}

(Поступило в Редакцию 10 апреля 2017 г.)

Разработан метод получения деталей сложной геометрической формы из композиционного материала на основе $\mathrm{SiC}$-керамики, который основан на взаимодействии расплава кремния с углеродной матрицей определенного состава и пористости. Для повышения рабочих температур керамических деталей разработана методика нанесения защитных карбидокремниевых покрытий, основанная на взаимодействии расплава и паров кремния с углеродом, получаемым при термическом расщеплении молекул углеводорода. Новая конструкционная керамика характеризуется более высокими рабочими температурами, химической стойкостью, механической, термоударной и радиационной прочностью, износостойкостью и стабильностью параметров.

DOI: $10.21883 /$ JTF.2017.12.45212.2291

Интерес к керамике и композитам на основе карбида кремния $(\mathrm{SiC})$ обусловлен уникальным сочетанием физико-химических свойств этих материалов, которые определяются сохранением высокой конструкционной прочности в высокотемпературном диапазоне $\left(1000-1500^{\circ} \mathrm{C}\right)$, высокой износостойкостью, стойкостью к многократным теплосменам и агрессивным средам, устойчивостью к радиационным воздействиям, высокой жаростойкостью и теплопроводностью, низким значением коэффициента линейного термического расширения, который позволяет керамике выдерживать термоциклические нагрузки, низкой плотностью и структурной стабильностью при длительных высокотемпературных нагружениях в окислительной атмосфере, доступностью сырьевых материалов для производства керамики [1-3].

Изделия из карбидокремниевой керамики находят применение в оборудовании для нефтедобывающей и нефтеперерабатывающей промышленности, на предприятиях, производящих электротермическое оборудование, в атомной энергетике, судостроении, в металлургической, химической промышленности, а также в качестве элементов газотурбинных двигателей для увеличения эксплуатационных температур, ведущих к существенному повышению их эффективности [3-7].

Наряду с технологическими сложностями получения (спекание порошка при высоких температурах при наличии и отсутствии связок и активирующих добавок, горячее прессование, реакционносвязанный и рекристаллизованный карбид кремния, силицированный графит и др. [1,2,7-14]) самих керамических материалов на основе $\mathrm{SiC}$, все вышеперечисленные методы накладывают жесткие ограничения на геометрическую форму получаемых заготовок (цилиндры, пластины, кольца). И, как следствие, одной из сложнейших задач является механическая обработка и изготовление деталей сложных форм из-за высокой твердости и хрупкости карбидокремниевой керамики. Этот фактор еще больше ограничивает широкое применение деталей из керамических материалов на основе $\mathrm{SiC}$ в машиностроении, так как традиционные методики получения готовых изделий сложной геометрической формы из керамики на основе $\mathrm{SiC}$ требуют последующей дорогостоящей механической обработки с использованием алмазного инструмента [15].

В ИФТТ РАН разработан ряд новых подходов к получению керамических карбидокремниевых материалов и деталей из них, благодаря которым удалось преодолеть трудности, связанные с получением изделий сложной геометрической формы из $\mathrm{SiC}$-керамики [13]. Разработанные подходы базируются на методе получения карбидокремниевых керамических материалов путем реакционного спекания, в котором используется механизм взаимодействия расплава кремния с углеродом (процесс силицирования) в заранее спрессованной заготовке, состоящей из углерода и порошка первичного $\mathrm{SiC}$ [16]. Химическая реакция расплава кремния и углерода, при которой образуется вторичный $\mathrm{SiC}$, обеспечивает образование связей между зернами первичного $\mathrm{SiC}$. Процесс реакционного спекания обеспечивает формирование контактов между зернами $\mathrm{SiC}$, заполнение пор и образование непрерывного поликристаллического каркаса из $\mathrm{SiC}$.

При разработке нашего метода [17] мы ставили перед собой задачу исключить из заготовки, подвергаемой взаимодействию с расплавом кремния, порошок первичного $\mathrm{SiC}$, который снижает механическую прочность заготовки, являясь абразивом, изнашивает оборудование и оснастку, а также не позволяет производить механическую обработку спрессованной заготовки на обычных станках твердосплавным инструментом (сверление, токарная и фрезерная обработка, обработка на станках с ЧПУ). Таким образом, для прессования заготовок применялись только углеродные порошки различных фракций и органическое связующее. 

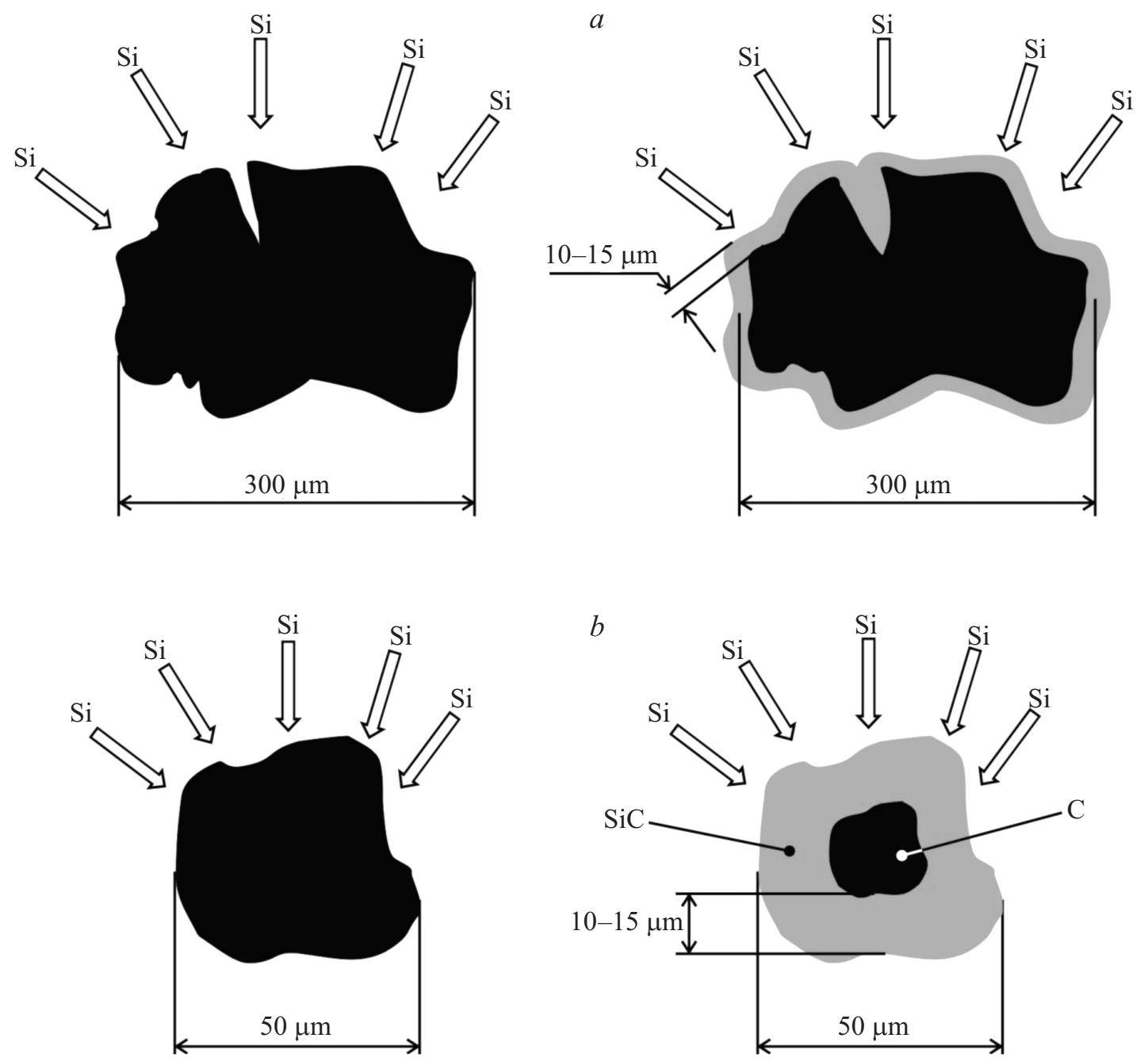

Рис. 1. Схематичное изображение взаимодействия частиц графита размером $300(a)$ и $50 \mu \mathrm{m}(b)$ с расплавом кремния.

Preparation of EG-84 carbon blank waste products
Comminution

with the use of hammermill DM-200
Undersize separation of specified fractions with the use of

vibrosieve SV2-09

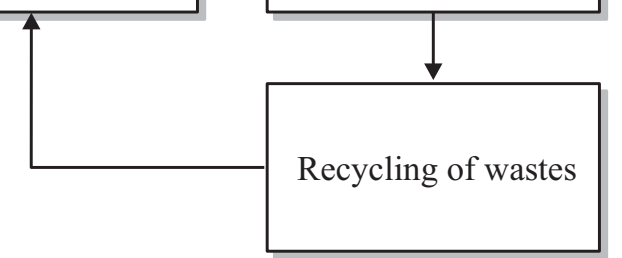

$$
\text { anto }
$$

Protective atmosphere annealing at $900^{\circ} \mathrm{C}$

Рис. 2. Блок-схема процесса получения углеродных заготовок. 
$a$

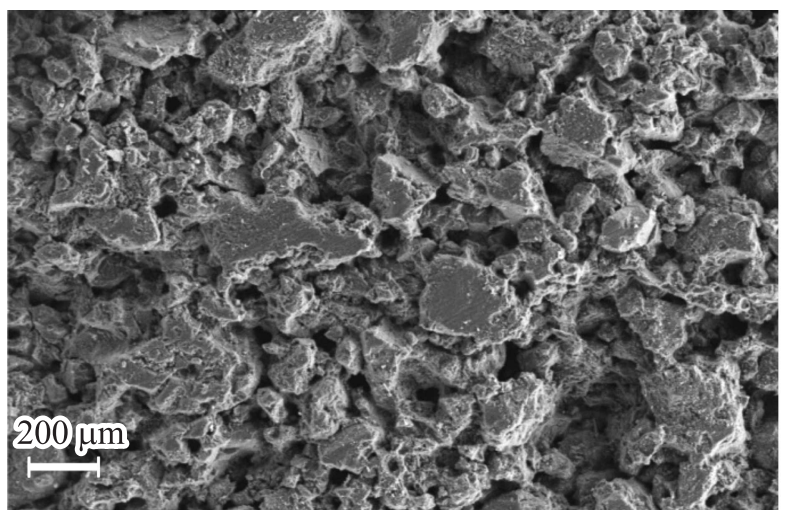

Рис. 3. Микроструктура углеродной заготовки плотностью 1.24 (a) и $0.93 \mathrm{~g} / \mathrm{cm}^{3}(b)$.

$a$
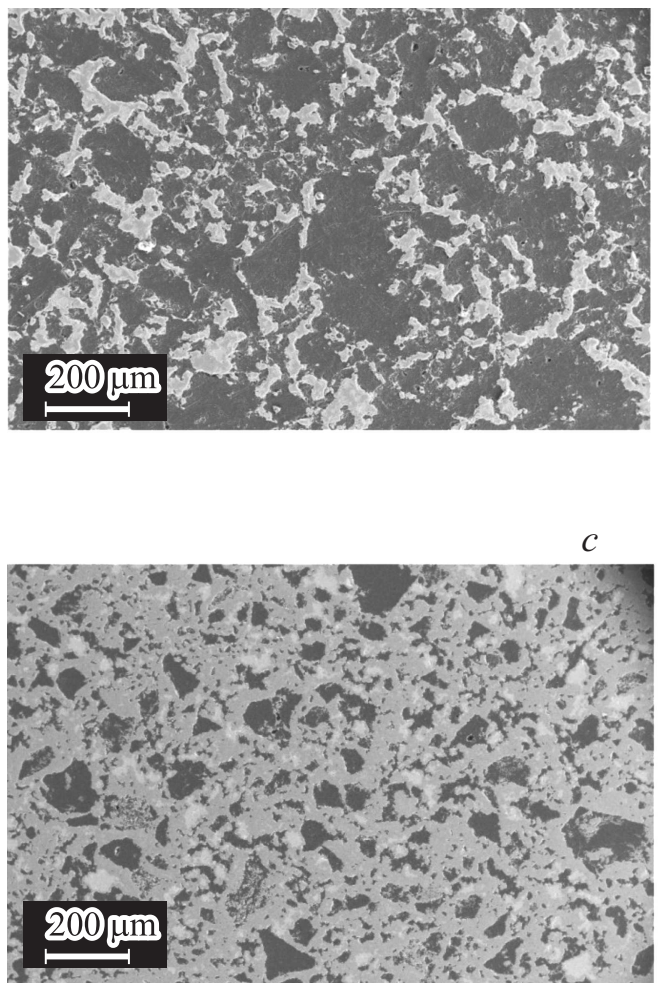

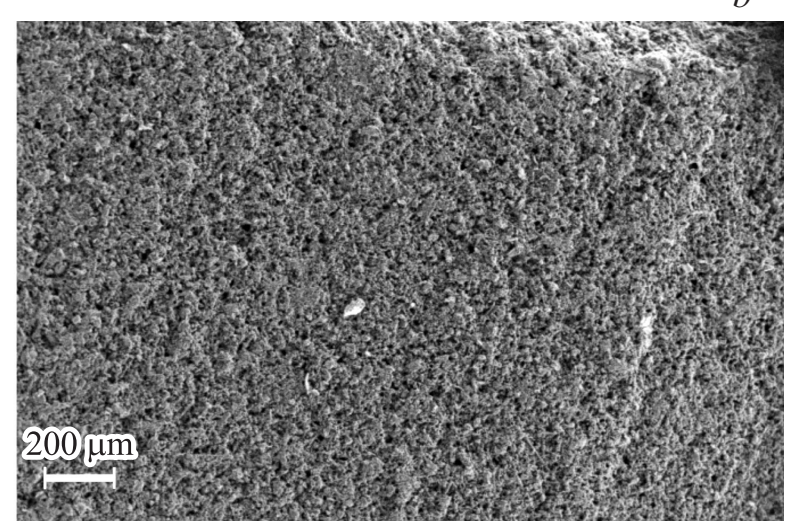

$b$

$b$

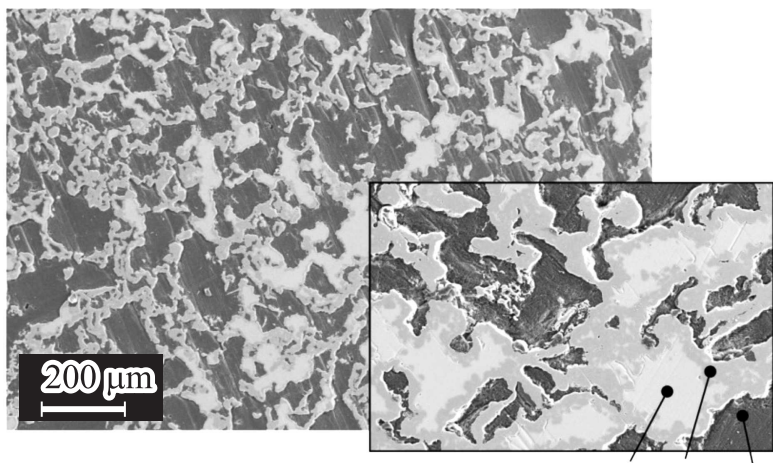

$\mathrm{Si} \mathrm{SiC} \mathrm{C}$

$d$

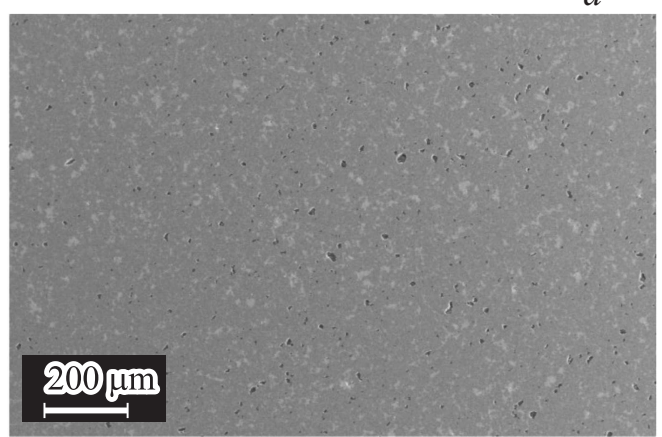

Рис. 4. Микроструктура керамик на основе $\mathrm{SiC}$ с различным фазовым составом $\mathrm{SiC} / \mathrm{C} / \mathrm{Si}: a-25 / 70 / 5$ (плотность углеродной заготовки $\left.1.46 \mathrm{~g} / \mathrm{cm}^{3}\right) ; b-40 / 50 / 10$ (на врезке - увеличенное изображение с указание фаз); $c-70 / 25 / 5, d-95 / 0 / 5$ (плотность углеродной заготовки $0.9 \mathrm{~g} / \mathrm{cm}^{3}$ ).

Силицирование углеродных матриц сопровождается сложными физико-химическими процессами, такими как растекание кремния по поверхности пористой углеродной заготовки с одновременной капиллярной пропиткой, реакция карбидообразования, протекающая на межфазной границе, выделение тепла на поверхности при силицировании и многими другими. Изучение механизма реакции на границе образования карбида кремния расплава кремния и углерода [7] показало, что поверхностный слой $\mathrm{SiC}$ формируется очень быстро (менее $1 \mathrm{~min}$ ) и в дальнейшем растет до максимальной толщины примерно $10-15 \mu \mathrm{m}$ в течение $10-15 \mathrm{~min}$, после чего рост слоя $\mathrm{SiC}$ практически приостанавливается и дальнейшее продолжение процесса силицирования нецелесообразно.

Замедление и практически прекращение роста слоя $\mathrm{SiC}$ связано с тем, что на всей границе раздела кремний-углерод образуется сплошной слой карбида кремния. Это изолирует области с оставшимся свободным углеродом от жидкого кремния, таким образом, предотвращая дальнейшее растворение углерода. 
$a$
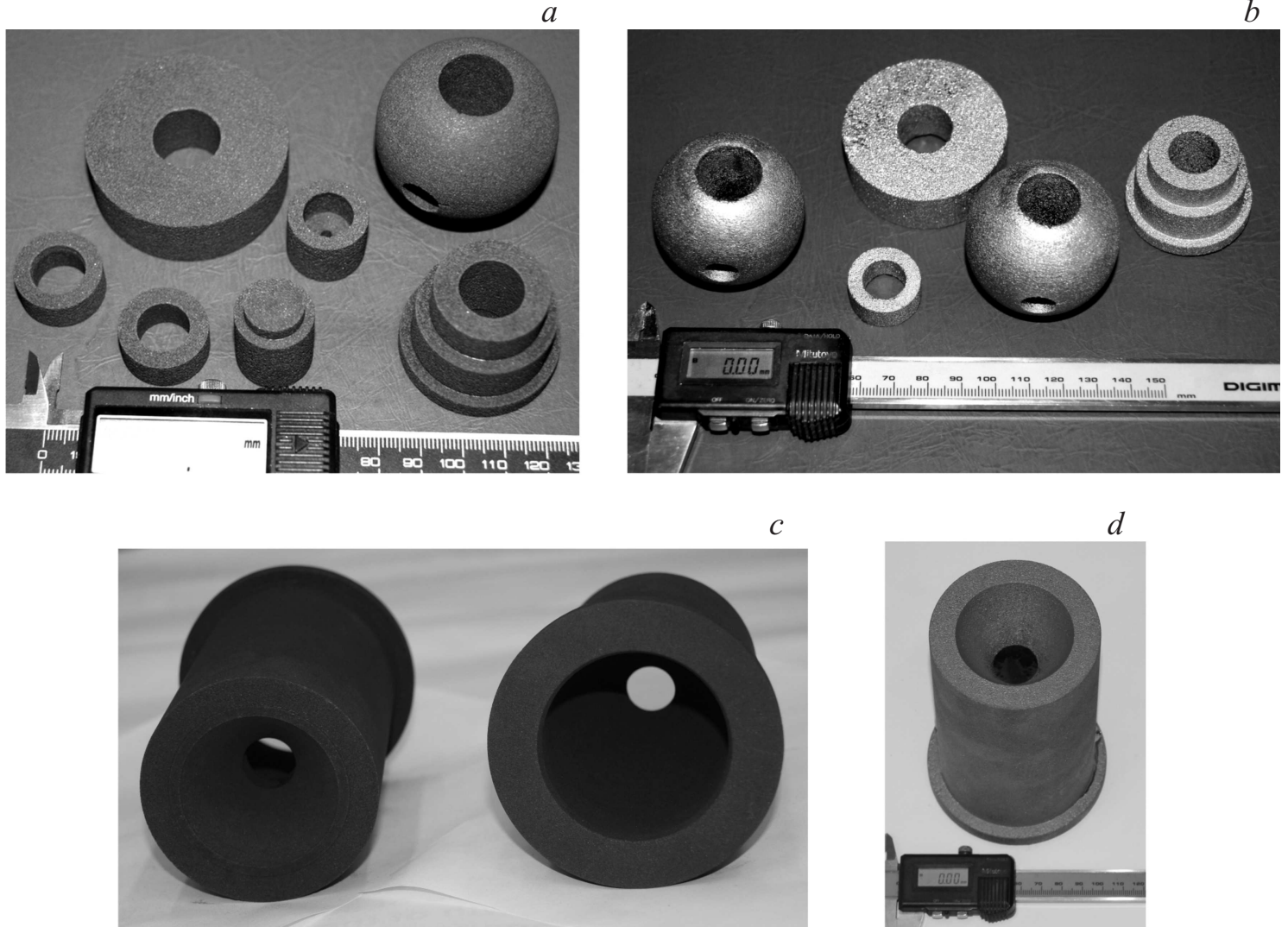

$d$

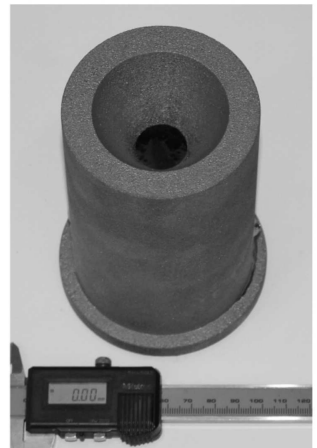

Рис. 5. Углеродные заготовки после механической обработки $(a, c)$ и соответствующие им карбидокремниевые детали после силицирования $(b, d)$.
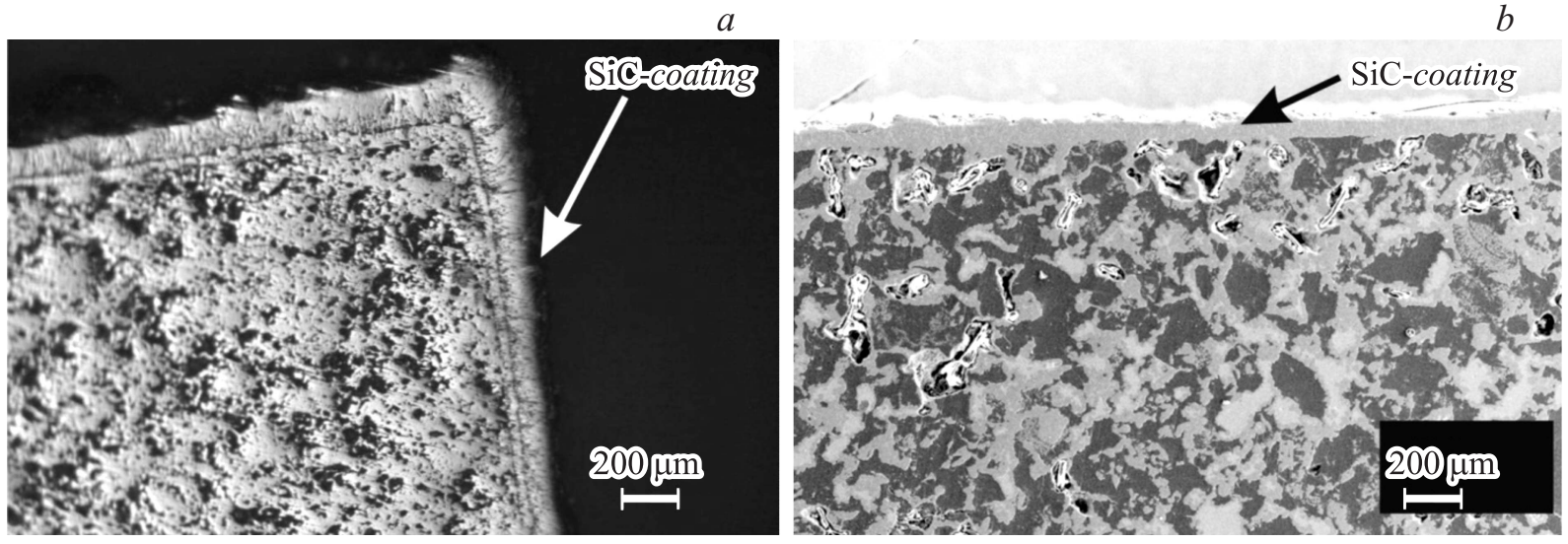

Рис. 6. Микроструктура композиционного материала $\mathrm{SiC}:(\mathrm{C}+\mathrm{Si})=50: 50$ с защитным покрытием из $\mathrm{SiC}$ : оптическая микроскопия $(a)$, SEM-изображение $(b)$.

Дальнейший рост карбида кремния может медленно продолжаться (со стороны расплава кремния) в случае пересыщения углеродом жидкого кремния до тех пор, пока концентрация углерода в расплаве кремния не понизится до равновесного уровня.

Основное влияние на скорость роста слоя $\mathrm{SiC}$ и его конечную толщину оказывает выбор марки графита (углеродного материала), применяемого для изготовления порошков. На рис. 1 схематично показано взаимо- действие частиц графита с расплавом кремния. Таким образом, изменяя размер частиц графита, можно влиять на степень перехода углерода в $\mathrm{SiC}$ при контакте с расплавом кремния.

Для изготовления пористых углеродных матриц нами был выбран графит марки ЭГ-83 (применяется при производстве щеток для электрических машин), из него помолом на молотковой дробилке ДМ-200 и последующим просевом на вибросите СВ2-09 были получены порошки 
$a$

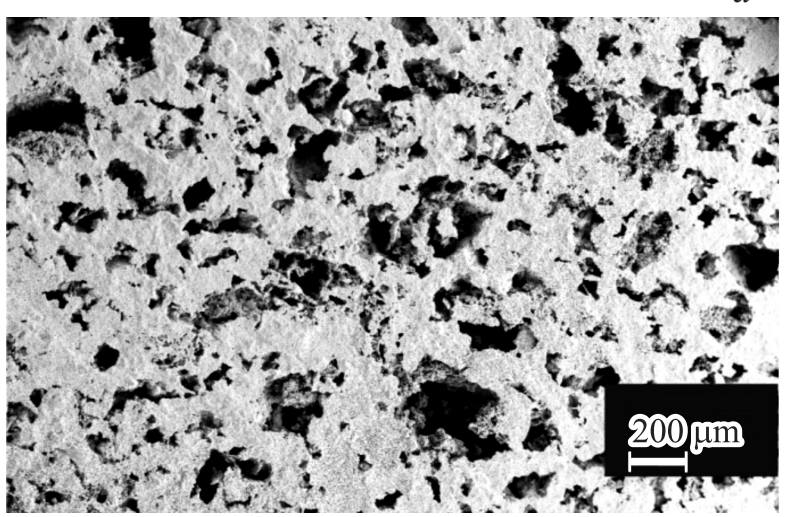

$b$

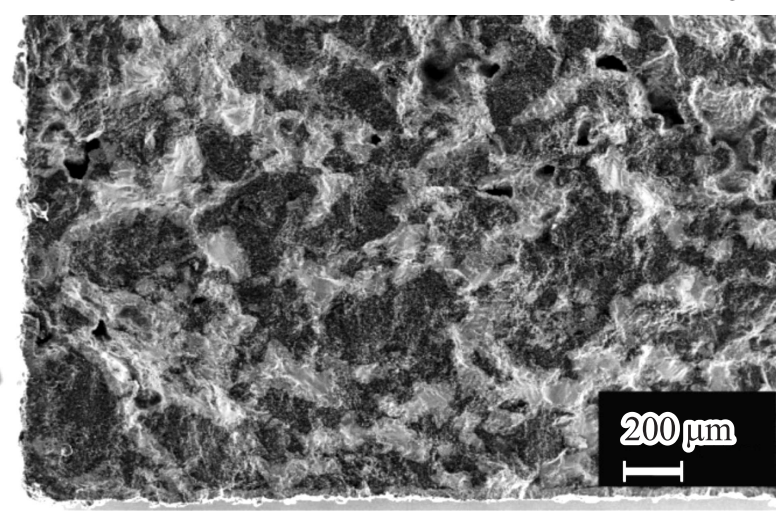

Рис. 7. Микроструктура $\mathrm{SiC}:(\mathrm{C}+\mathrm{Si})=50: 50$ материала после отжига при $1000^{\circ} \mathrm{C}$ на воздухе в течение $60 \mathrm{~h}$ : без покрытия $(a)$ и с $\mathrm{SiC}$-покрытием толщиной $40 \mu \mathrm{m}(b)$.

$a$

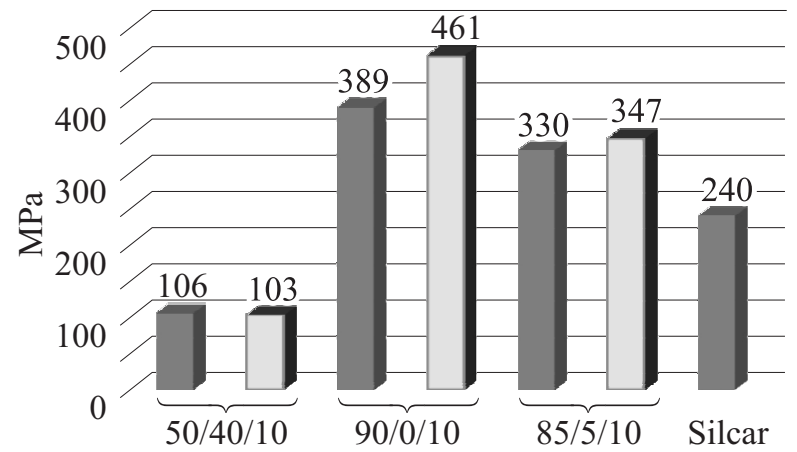

(TOKKUUM)

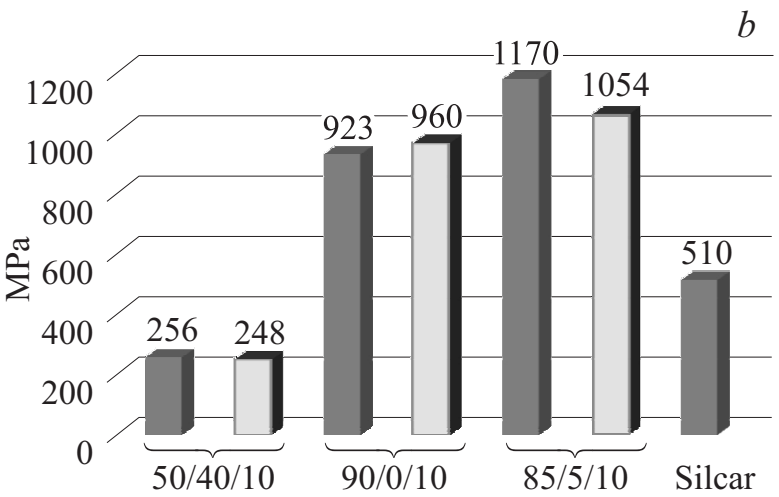

(TOKKUUM)

Рис. 8. Прочность различных типов керамических материалов на основе карбида кремния $(\mathrm{SiC} / \mathrm{C} / \mathrm{Si})$ при температурах $20^{\circ} \mathrm{C}$ (темные столбцы) и $1000^{\circ} \mathrm{C}$ (светлые столбцы) при изгибе $(a)$ и сжатии $(b)$. Испытания проводились на 5 образцах материалов каждого типа, приведены средние значения прочности.

различных фракций. Для подготовки шихты использовались в разных соотношениях порошки фракций: +0.315 , $+0.100,+0.063,+0.05,-0.05$, в качестве связующего использовался пульвербакелит марки СФПН-011Л. Блок-схема процесса получения углеродных заготовок изображена на рис. 2.

Варьируя соотношение порошков графита различных фракций, количество связующего и давление прессования, после карбонизации связующего (в защитной атмосфере при $900^{\circ} \mathrm{C}$ ) получали пористые графитовые заготовки плотностью от 0.9 до $1.46 \mathrm{~g} / \mathrm{cm}^{3}$. На рис. 3 показана микроструктура углеродных заготовок различной плотности.

Метод позволяет в широких пределах изменять фазовый состав (соотношение фаз $\mathrm{SiC}-\mathrm{C}-\mathrm{Si}$ ) и структуру керамики в зависимости от требований, предъявляемых условиями эксплуатации конкретного изделия. Для прогнозирования плотности и фазового состава $\mathrm{SiC}-\mathrm{C}-\mathrm{Si}$-материалов, полученных силицированием углеродных матриц, разработана методика расчета фазового состава $\mathrm{SiC}-\mathrm{C}-\mathrm{Si}$-материалов, получаемых си- лицированием углеродных матриц [18]. Показано, что расчетный фазовый состав всех исследованных материалов хорошо согласуется с экспериментальными данными. После силицирования углеродных матриц получены материалы на основе $\mathrm{SiC}$-керамики плотностью от 2.32 до $3.1 \mathrm{~g} / \mathrm{cm}^{3}$ при использовании углеродных заготовок плотностью 1.46 и $0.9 \mathrm{~g} / \mathrm{cm}^{3}$ соответственно. Изменение микроструктуры и фазового состава материалов в зависимости от плотности углеродной заготовки показано на рис. 4.

Все получаемые таким способом углеродные заготовки обладают достаточной прочностью для их механической обработки на сверлильном, токарном, фрезерном, ЧПУ станках обычными твердосплавными инструментами, при использовании режимов обработки, применяемых к обычным низко- и среднеплотным графитам, рис. $5, a, c)$.

Важно отметить, что после силицирования изменение размеров углеродных деталей составляют десятые доли процента, т.е. геометрическая форма и размеры сохраняются. Таким образом, отсутствие усадок после 


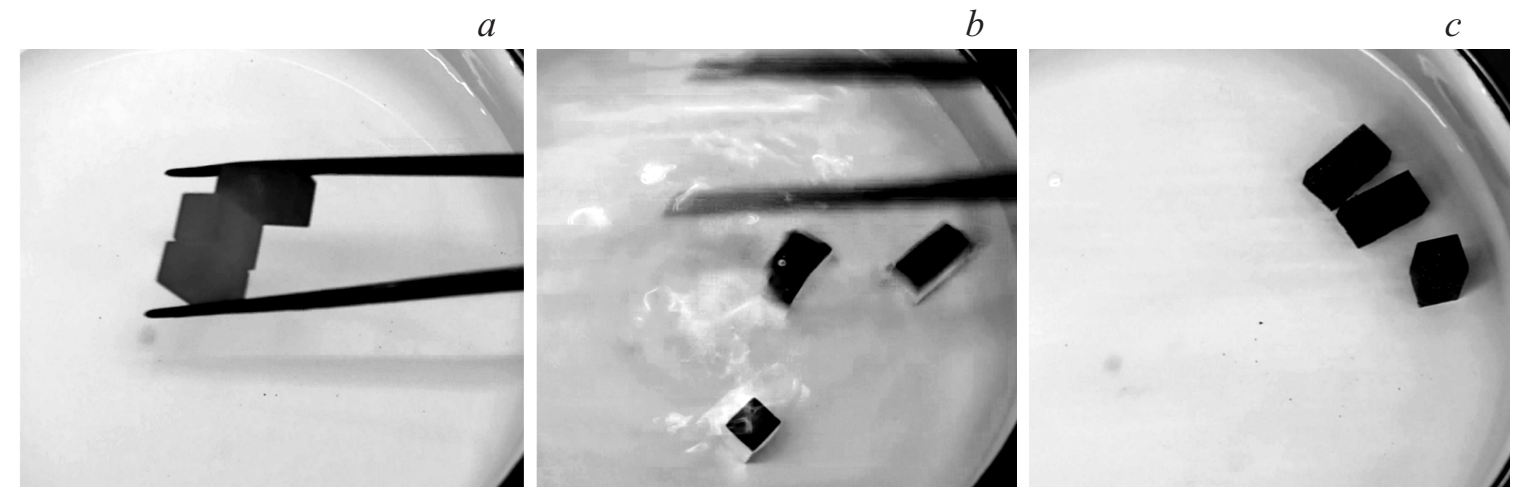

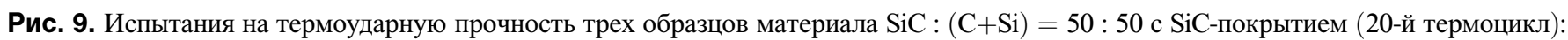
образцы, нагретые до температуры $1100^{\circ}$ (слева); охлаждение образцов в воде при комнатной температуре (справа). Временной интервал между первой и последней фотографиями $-7 \mathrm{~s}$.

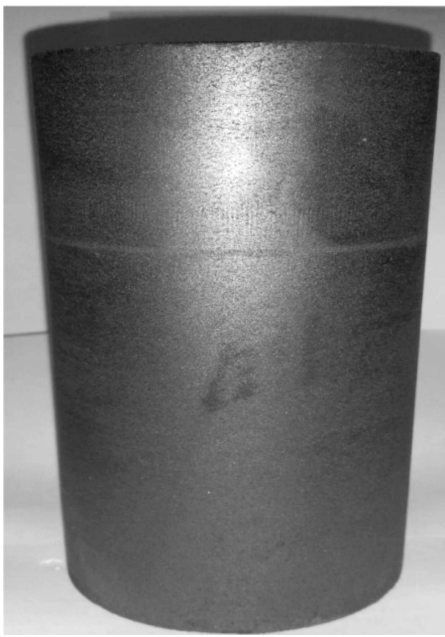

$b$

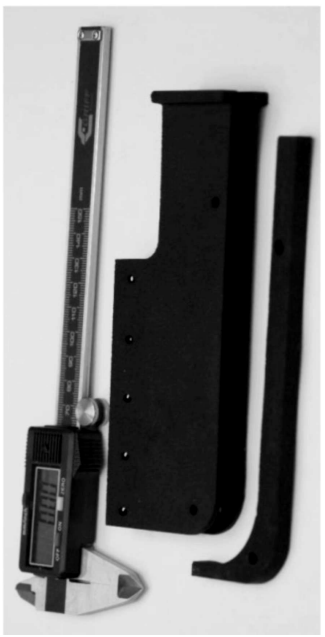

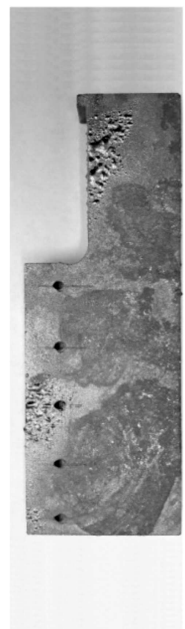

$d$

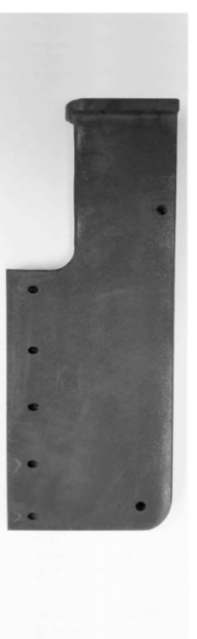

$e$

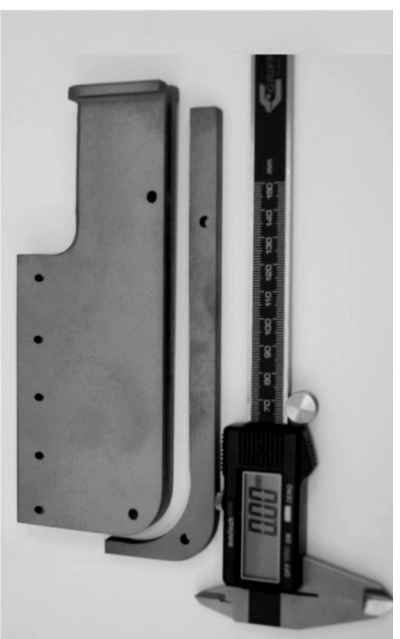

Рис. 10. Этапы изготовления керамической карбидокремниевой детали для работы в высокоскоростном газовом потоке при температуре более $1500^{\circ} \mathrm{C}: a-$ объемная заготовка из углеродной пористой матрицы; $b-$ углеродная заготовка после механической обработки; $c$ - керамическая заготовка после силицирования; $d-$ керамическая деталь после финишной обработки; $e$ - деталь с нанесенным защитным $\mathrm{SiC}$-покрытием.

взаимодействия с кремнием позволяет создавать детали сложной геометрической формы, обрабатывая мягкую углеродную заготовку, и после силицирования получить деталь из керамики на основе $\mathrm{SiC}$ с минимальным припуском на последующую финишную механическую обработку, рис. $5, b, d$.

Поскольку во всех полученных материалах в том или ином количестве содержатся остаточные углерод и кремний, то для повышения термоокислительной стойкости деталей была разработана методика нанесения на их поверхность газоплотного покрытия из $\mathrm{SiC}[19,20]$. Методика основана на взаимодействии расплава и паров кремния с углеродом, получаемым при термическом расщеплении молекул углеводорода, вводимого непосредственно в тепловую зону вакуумной печи. В зависимости от условий в зоне взаимодействия, парциального давления газа и времени проведения процесса можно в широких пределах менять толщину карбидокремниевого покрытия.

На рис. 6 показана микроструктура поперечного сечения композиционного материала $\mathrm{SiC}-\mathrm{C}-\mathrm{Si}$ с защитным покрытием из $\mathrm{SiC}$, полученным высокотемпературным синтезом из газовой фазы.

B отличие от CVD-метода осаждения слоя карбида кремния с использованием различных прекурсоров (монометилсилан, метилтрихлорсилан, тетраметилсилан и др.) [21] разработанный нами высокотемпературный способ газофазного нанесения защитных $\mathrm{SiC}$-покрытий обладает рядом существенных преимуществ: (1) увеличение скорости нанесения покрытий примерно на два порядка; (2) адгезия защитного покрытия с поверхностью керамики при использовании нашей методики существенно выше, так как процесс проводится при высокой температуре с участием углерода и кремния, 
находящихся непосредственно в керамической детали; простота и дешевизна нанесения покрытий.

Газоплотные защитные SiC-покрытия существенно повышают термоокислительную стойкость керамических $\mathrm{SiC}-\mathrm{C}-\mathrm{Si}$-материалов. На рис. 7 показана микроструктура образцов материала на основе карбида кремния после отжига при $1000^{\circ} \mathrm{C}$ на воздухе в течение $60 \mathrm{~h}$. Видно, что структура материала при отсутствии защитного покрытия сильно нарушена за счет выгорания углерода. Эффективность работы защитного покрытия также подтверждается результатами взвешивания образцов до и после отжига. Потеря веса детали без покрытия достигает 50\%; вес детали с защитным покрытием при тех же условиях испытания не изменился.

Защитные антикоррозионные покрытия из карбида кремния позволяют $\mathrm{SiC}-\mathrm{C}-\mathrm{Si}$-материалам работать в условиях окислительных сред при температурах более $1500^{\circ} \mathrm{C}$.

Сравнительные прочностные испытания на изгиб и сжатие при температурах $20^{\circ} \mathrm{C}$ и $1000^{\circ} \mathrm{C}$ показали, что полученные нами материалы плотностью более $3.0 \mathrm{~g} / \mathrm{cm}^{3}$ по своим характеристикам превосходят реакционносвязанные $\mathrm{SiC}$-керамики и практически не уступают горячепрессованным $\mathrm{SiC}$-керамикам. На рис. 8 приведены результаты испытаний и их сравнение с заявленными характеристиками реакционно-связанной

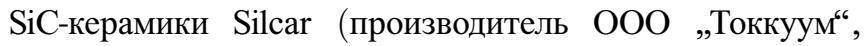
Москва). Для материалов с содержанием $\mathrm{SiC} 50 \%$ вес. приведено сравнение с материалом СГ-П 0.5 (производитель АО „НИИ Графит“).

Существенным достоинством разработанной карбидокремниевой керамики в сочетании с защитными покрытиями является высокая стойкость к термоудару, которая значительно превосходит керамические изделия на основе карбида кремния, присутствующие в настоящее время на коммерческом рынке. Испытания керамических карбидокремниевых материалов на термоударную прочность проводили путем погружения в холодную воду образцов, нагретых до температуры $1100^{\circ} \mathrm{C}$, рис. 9. На части образцов из высокоплотной керамики (содержание $\mathrm{SiC}>85 \%$ ) появились трещины после 15-20 циклов. Керамические образцы из $\mathrm{SiC}:(\mathrm{C}+\mathrm{Si})=50: 50$ с $\mathrm{SiC}$-покрытием выдержали 25 циклов без каких-либо повреждений.

Сочетание возможности получения керамических деталей сложной геометрической формы из мягкой углеродной матрицы, высокой прочности, термоударной и высокотемпературной химической стойкости новой керамики с защитными антикоррозионными покрытиями существенно расширяет диапазон ее практического применения. В частности, на рис. 10 показана последовательность операций по получению готовой керамической детали сложной геометрической формы, работающей в высокоскоростном газовом потоке при температурах более $1500^{\circ} \mathrm{C}[22]$.

\section{Заключение}

В ИФТТ РАН разработаны новые подходы к получению многофункциональной карбидокремниевой керамики, которые основаны на взаимодействии расплава кремния с углеродом, находящимся в заранее скомпонованной заготовке определенного состава и пористости. Исходная углеродная матрица может обрабатываться обычными резцами для получения сложных геометрических форм. После этого углеродная заготовка взаимодействует с расплавом кремния с образованием карбида кремния. Отсутствие усадок после силицирования позволяет создавать детали сложной геометрической формы с минимальным припуском на последующую механическую обработку. Метод позволяет в широких пределах изменять фазовый состав (соотношение фаз $\mathrm{SiC}-\mathrm{C}-\mathrm{Si}$ ) и структуру керамики в зависимости от требований, предъявляемых условиями эксплуатации конкретного изделия.

В сравнении с традиционными керамическими материалами на основе $\mathrm{SiC}$, новая конструкционная керамика обладает более высокими рабочими температурами, химической стойкостью, механической, термоударной и радиационной прочностью, износостойкостью, надежностью, ресурсом эксплуатации и стабильностью параметров.

Разработана методика получения карбидокремниевых покрытий на основе взаимодействия расплава и паров кремния с углеродом, получаемым при термическом расщеплении молекул углеводорода. Защитные антикоррозионные покрытия позволяют работать изделиям из карбидокремниевой керамики в условиях окислительных сред при температурах, превышающих $1500^{\circ} \mathrm{C}$.

Работа выполнена при частичной поддержке Программы фундаментальных исследований ОФН РАН „Новые материалы и структуры“, гранта Правительства Московской области „Высокотемпературные композиционные материалы на основе карбида кремния для конструкционных применений“ (распоряжение № 403РП от 03.08.2017), а также РФФИ и Правительства Московской области в рамках научного проекта № 17 43-500079.

Авторы благодарны Л.Я. Шикунову, И.А. Шикуновой, А.Е. Ершову и Н.В. Сурмину за помощь в работе.

\section{Список литературы}

[1] Somiya S., Inomata Y. Silicon Carbide Ceramic. Berlin: Springer, 1991. P. 305.

[2] Гнесин Г.Г. Карбидокремниевые материалы. М.: Металлургия, 1977.

[3] Ceramic Matrix Composites. Fiber Reinforced Ceramics and their Applications (ed. Krenkel W.). Weinheim, Germany: Wiley_VCH, 2008. P. 418.

[4] Schwetz K.A. Handbook of Ceramic Hard Materials (ed. Riedel R.). Weinheim, Germany: Wiley_VCH, 2000. P. 683. 
[5] Watari K. // Ceram. Societ. Jap. 2001. Vol. 109. N 1265. P. S7-S16.

[6] Гаршин А.П., Карлин В.В., Олейник Г.С. Конструкционные карбидокремниевые материалы Л.: Машиностроение, 1975. C. 152.

[7] Handbook of Ceramic Composites (ed. Bansal N.P.). Kluwer Academic Publishers, 2005. P. 554.

[8] Электронные ресурсы. Режим доступа: http://www.hexoloy.com

[9] Singh M., Behrendt D.R. // Mater. Sci. Eng. A. 1994. Vol. 187. P. $183-187$.

[10] Аникин Л.П., Костиков В.И., Кравецкий Г.А. // Конструкционные материалы на основе графита. М.: Металлургия, 1970. C. 143.

[11] Гегузин Я.Е. // Физика спекания. М.: Наука, 1967. С. 360.

[12] Corman G.S., Luthra K.L., Brun M.K. // in: Progress In Ceramic Gas Turbine Development. Vol. II. Ceramic Gas Turbine Component Development and Evolution, Fabrication, NDE, Testing and Life Prediction (ed. van Roode M., Ferber M., Richerson D.). N.Y., USA: ASME Press, 2003.

[13] Filonov K.N., Kurlov V.N. etal. // Bull. Russ. Acad. Sci.: Physics. 2009. Vol. 73. N 10. P. 1377-1379.

[14] Костиков В.И., Самойлов В.М., Бейлина Н.Ю., Остронов Б.Г. // Российский хим. журн. 2004. Т. XLVIII. № 5. C. 64-75.

[15] Yan J., Zhang Zh., Kuriyagawa T. // Intern. J. Machine Tools \& Manufacture. 2009. Vol. 49. P. 366-374.

[16] Шикунов С.Л. идр. // Материаловедение. 2012. № 5. C. 51-57.

[17] Пат. РФ № 2573146. Композиция углеродной заготовки для получения $\mathrm{SiC} / \mathrm{C} / \mathrm{Si}$ керамики и способ получения $\mathrm{SiC}-\mathrm{C}-\mathrm{Si}$ изделий. Курлов В.Н., Шикунов С.Л., Шикунова И.А. 2015.

[18] Ершов А.Е., Шикунов С.Л., Курлов В.Н. // ЖТФ. 2017. Т. 87. Вып. 6. С. 888-895.

[19] Filonov K.N., Kurlov V.N. etal. // Bull. Russ. Acad. Sci.: Physics. 2009. Vol. 73. N 10. P. 1374-1376.

[20] Пат. РФ № 2601049. Способ нанесения газоплотного покрытия из карбида кремния. Курлов В.Н., Шикунова И.А., Шикунов С.Л., Ершов А.Е. 2016.

[21] Liu R.J. et al. // J. Mater. Sci. 2005. Vol. 40. P. 2109-2111.

[22] Пат. РФ. № 160313. Гребенка термопар для измерения поля температур газового потока. Курлов В.Н., Шикунов С.Л., Ершов А.Е., Шикунова И.А., Сурмин Н.В., Тихомирова Е.В., Гришихин С.А., Тихонов Е.Г., Белякова Т.Б. 2016. 